\title{
INTERNAL MIGRATION OF POPULATION FROM VILLAGES TO CITIES AS A RESULT OF SOCIO-ECONOMIC AND INNOVATIVE DEVELOPMENT OF CHINA
}

\author{
Krasova E.V. ${ }^{*}$, Candidate of Economic Sciences \\ Chen Y., Graduate student \\ Vladivostok State University of Economics and Service, Vladivostok, Russia
}

*E-mail: elena krasova@rambler.ru

\begin{abstract}
Intensification of internal migration of population from villages to cities is the important process that accompanies the social and economic development of modern China. Active internal migration is the result of industrial and innovative development of the country, when developing provinces and large cities required a large number of labor force. The main scientific and practical problem of the research is the presence of a number of problems caused by migration of huge masses of people from villages to cities in China. The purpose of the article is actualization of trends reflecting the intensification of internal migration of population from villages to cities as a result of active socio-economic and innovative development of the country. The methodological basis of the research is the theses of modern economic and demographic theories, the concept of country's migration development. The article reveals the importance of migration processes for development of China's economy, focuses on internal migration from villages to cities. The authors describe the factors and conditions that take place in China for development of internal migration and national human potential, indicate the difficulties that the country faces with in such large population movements. The article also presents basic statistics in the field of Chinese internal migration, its composition and structure.
\end{abstract}

\section{KEY WORDS}

Internal migration in China, migration from villages to cities, Chinese economy, socioeconomic development, innovative development, labor potential, factors of migration development, Chinese population.

Rapid development of processes in internal migrations of population and labor force in China has generated a large number of scientific researches in the field of dynamics, regulation, and factors of development of internal migration processes. In modern economic science a special attention is paid to concepts, typology, varieties of internal migration, urbanization processes, etc., which are taken as a part of studying in the field of human capital and reproduction of labor resources. These aspects of studying reveal the fundamental features of internal migration and determine the trends of their development.

China's government has always paid a great attention to the processes of labor migration. The role of labor movement of population in geographical and economic sense, the significance of state instruments that regulate involvement and use of national labor force in the territories of Chinese provinces, increase from year to year. Obviously, in many provinces and cities of central subordination, such as Beijing, Tianjin, Shanghai, the processes of internal labor migration play a determining role in the resource provision of the economy and socio-economic development. Studying the regional aspects of internal labor migration in China, we can face the problem of a lack of detailed and structured assessment of migration potential in this country [1].

It is important to emphasize the peculiarities of internal migration flows in China over the past half of the century - their constant expansion and qualitative transformation. Chinese scientists consider migration as a part of national economy and at the same time as a part of national demography. Regional labor flows were created and formed. They take an active part in formation and development of labor markets in Chinese provinces and cities. 
These facts determine the relevance of the research theme and its need for the growing Chinese economy. The study of internal migrations in many ways makes necessary to determine the nature, magnitude and degree of influence of factors forming the regional labor markets on each other, makes possible to identify the causes and proportion of social and economic parameter associated with the demographic development, the labor market, the development of human capital, etc. [2].

According to modern demographic theories, there are two main types of migration: external and internal. External migration is a type of movement in which national borders are crossed. Internal migration is a movement of population within the borders of the country. Geographically they consist of four streams: from city to city; from village to city; from city to village; between rural settlements (figure 1).

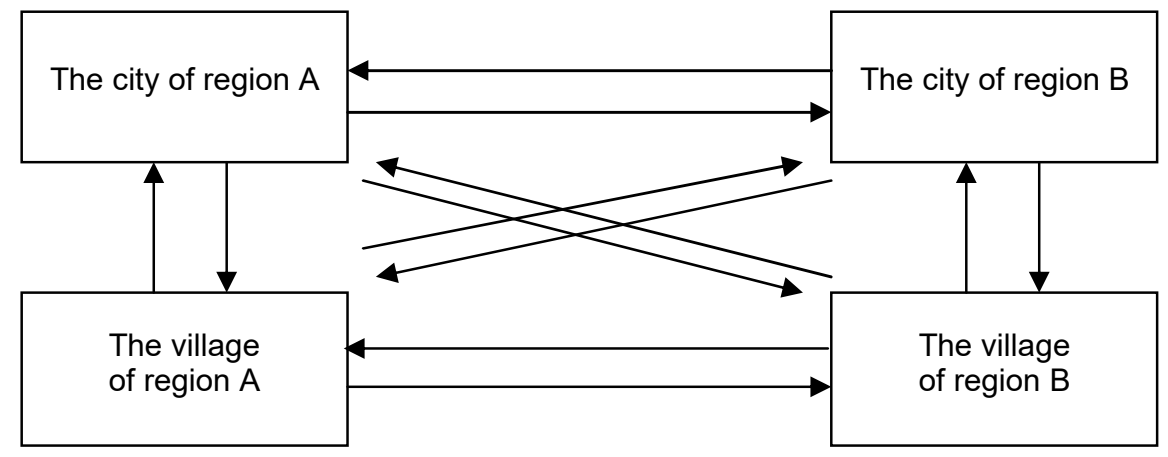

Figure 1 - The scheme of internal migration (interregional and intraregional)

Internal migration includes movements within the one country between administrative or economic-geographical populated areas. The most common modern type of internal migration is a movement from rural areas to cities and inter-district migration [3]. They take approximately $70 \%$ of all internal flows of migrants in China.

Such rapidly developing country like China, systematically and comprehensively forms conditions for innovative wave of its development that suggests accumulation and improvement of quality of the human capital. China began its reforms with a completely technocratic approach to management of human resources and migration flows, in which the large, illiterate and disenfranchised labor force was subordinated to needs of national production and was directed to way the state needs. According to experts' assessments, the existence of almost unlimited resource of labor, its migration after the capital to the points of economic growth, provided during the period 1978-1988 about a third of GDP growth [4]. In 1980 after creation of the concept of sustainable development, which China began to adhere to, Chinese society began to move toward the humanistic approach in management of population migration. The strategy of comprehensive construction of a moderately prosperous society, which was fixed at the 16th Congress of the Chinese Communist Party in 2002, clearly identified the rise of ideological, moral, scientific, cultural and physical qualities of the nation as one of the tasks that can to create a perfect modern system of public education, technical and cultural innovation, the system of nation-wide physical training, as well as medical care and public health, can to stimulate the comprehensive development of personality [5].

\section{RESULTS AND DISCUSSION}

At present time, following their Western colleagues, Chinese scientists view their national human potential as one of the most important strategic resources that determine the complex power of the state and form the "hard» power (material resources), which with the "soft» power (culture and mentality) provide China's national competitiveness in the global economy [6]. At the same time, many researchers reflect the duality and inconsistency of 
migration and demographic situation in China and connect it with the policy of birth control "One family - one child», which was started in 1979. The main negative consequence of this policy is reduction of working-age population and its aging. Many specialists connect with the policy a whole complex of social and economic problems, including internal migration problems [7].

Summarizing all that was said before, we can note the following factors and conditions in which internal migration in China has developed and continues to evolve:

1) Large number of the working-age population, not burdened with a family and children, aimed at work and earnings;

2) Reduction of growth rates of the working-age population because of the policy «One family - one child» during the 1980-2015 [8];

3) Concentration of economic and labor potential in eastern territories of the country, lag of economic development in the central and western territories of China [9];

4) Development of specific settlements and territories (provinces, districts, cities, cities of central subordination) as industrial, innovative, educational and tourist centers, which require a particularly highly skilled workforce and large number of workers;

5) Differentiation of living standards of Chinese population as a result of the difference in economic and investment development, the desire of population to move to territories that have potential for getting a good job and a high salary [10];

6) Level of education of the population continues to be low. It is easier for the less educated people to move to another place of residence than to educated people who, as a rule, have good jobs in their cities.

The volume of internal migration increases every year in China because of these socioeconomic and demographic factors. The main reason for large-scale internal labor migration is the differentiation of standard of living, which pushes out a part of population in search of a better life. According to some experts' opinions, the large structural changes in China's economy led to creation of the largest migration flow of people in the history of modern civilization in peacetime. The number of people leaving the rural areas and seeking work in large industrial cities increased from 2 million in 1985 up to 250 million now [11]. Such mass of migratory people undoubtedly has a significant impact on China's economics and politics and at the same time on the neighboring countries. This fact makes labor migration one of the key and most important problems that China faces today.

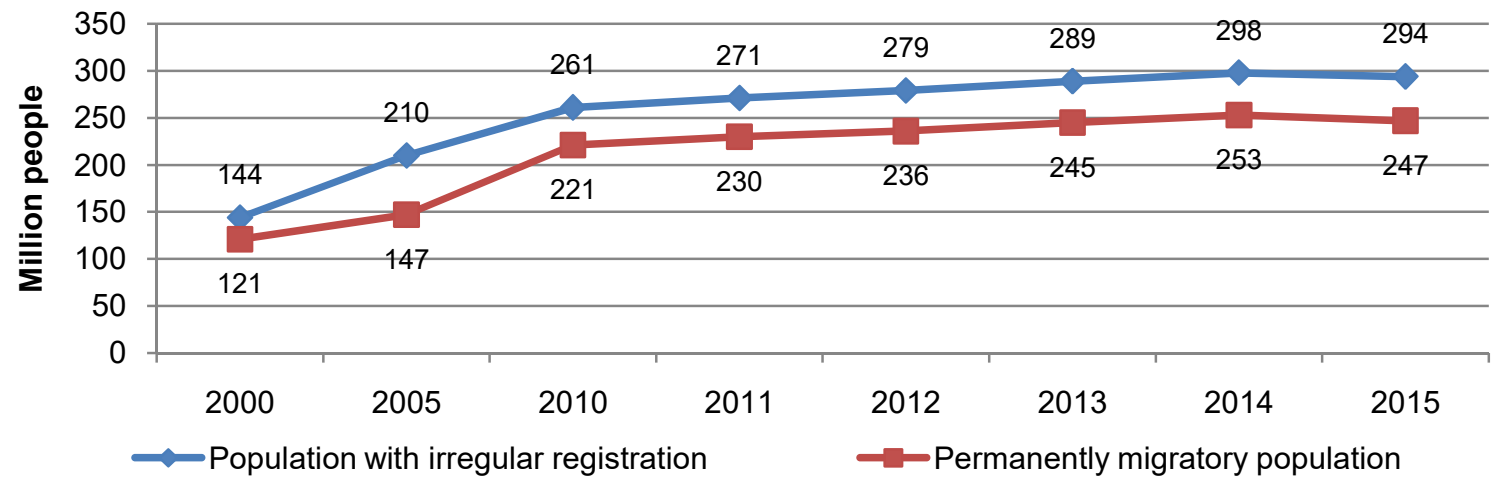

Figure 2 - Dynamics of number of migratory populations and population with irregular registration in China for 2000-2015

As in any other countries, China has different directions of internal migration: interregional (city-city), intraregional (village-city). The most of all internal migrations is concentrated in the framework of intraregional migrations and reflects movements from villages to cities. In the vast majority of cases, the purpose of migration is to find work, so we can say that the labor migration in Chine is mainly caused by economic reasons [12].

According to data of the Department of Control of the Migratory Population under the Municipal Committee for Population and Family Planning of China, in 2015 the number of 
migrants in the country reached 247 million people. The trend in China's migratory population reflects a positive trend (figure 2) [11].

During the period 2000-2015 the number of migrants annually increased by 126 million people, or more than 2 times. The number of people with irregular registration increased by 150 million people, or also by 2 times. The number of residents with irregular registration is always more than the number of migrants, because it reflects those who have already arrived to a new place, but continues to live with the old residence permit. It can be assumed that the number of migrants and persons with irregular registration will increase and in 2050 will reach 350 million people [13].

The army of migrants has a significant influence on the livelihoods of cities, which are the final destination of their migration potential. The data of the National Bureau of Statistics of China indicate a permanent restructuring in number of urban residents in favor of visitors and those who live in them for less than 6 months (table 1) [11].

Table 1 - The structure of population in China on the basis of registration

(According to results of the National sample survey 2011 and 2015 about the change in population structure. The sample's share is $1.55 \%$ in 2015 and $0.850 \%$ in 2011), millions of people

\begin{tabular}{|l|c|c|}
\hline \multicolumn{1}{|c|}{ Indicators } & 2015 & 2011 \\
\hline The number of surveyed population & 213,12 & 11,45 \\
\hline $\begin{array}{l}\text { Living in cities and settlements with a permanent registration (share in the total } \\
\text { sample) }\end{array}$ & $166,50(78,1 \%)$ & $9,09(79,4 \%)$ \\
\hline $\begin{array}{l}\text { Living in cities and settlements with a permanent registration in another place } \\
\text { for more than 6 months (share in the total sample) }\end{array}$ & $45,46(21,3 \%)$ & $2,24(19,5 \%)$ \\
\hline $\begin{array}{l}\text { Living in cities and settlements without a permanent registration (share in the } \\
\text { total sample) }\end{array}$ & $0,89(0,42 \%)$ & $0,10(0,89 \%)$ \\
\hline $\begin{array}{l}\text { Living in Hong Kong, Macao and Taiwan, as well as abroad, with a permanent } \\
\text { registration in Chinese cities and settlements (share in the total sample) }\end{array}$ & $0,27(0,13 \%)$ & $0,02(0,77 \%)$ \\
\hline
\end{tabular}

Experience of the selective statistics in China shows that over the past 5 years from 2011 to 2015 the proportion of those who do not have permanent registration and those whose registration does not coincide with their actual place of residence, has increased from $21.16 \%$ to $23.85 \%$. The sample volume has increased significantly. This fact indicates a significant scale of internal migration of population, which is registered by statistics.

According to Chinese experts' opinion, $70 \%$ of migrants are people from 16 to 35 years old. Most of them have primary or incomplete secondary education (9 classes). Most of the migrants earn 300 to 600 yuan per month (from 36 to 72 US dollars). About a third of migrants are women. Most of migrants are hired for work, which is usually considered as dirty, dangerous or heavy and is not attractive to local residents. The average age of these migrants is 27.3 years old; $78.7 \%$ of them are peasants; the average composition of families of these people is 2.3 people; $86.8 \%$ of them graduated from high school only. Currently, the majority of migrants are engaged in construction, trade, food industry, provides various services [13]. Because of large number and specificity of their composition and structure, migrants have a very serious impact on life in cities. We can distinguish both advantages and disadvantages of the migrants' influence.

Speaking about the advantages, scientists note that internal labor migration has made a significant contribution to the growth of China's economy, providing $16 \%$ of GDP growth in China for the past 20 years. Speaking about disadvantages we can note that consideration of issues connected to internal migration makes possible to identify sectoral and geographical disparities in the country's economic development. Migration is a factor contributing to China's industrial development, to solution of the poverty problems and implementation of strategy for rural development. As in other countries in which cheap labor force is a comparatively competitive advantage, in China the border between use of labor and its exploitation is often blurred. Tens of millions of labor migrants from rural areas have become a live tool for acceleration of urbanization and industrial development of the country. But they remain second-class citizens who do not have rights, social protection and access to social life system [14]. 
In March 2015, Prime Minister Li Keqiang held a series of meetings and forums to promote the rapid and full adaptation of migrants in the host territories, the development of mass entrepreneurship and popular innovations among them. According to the Department of Trade and Industry of the Ministry of Economic Development of China, increasing the viability of labor market, reducing barriers to entry into the market and formation of full demand are the priority task for China. The implementation of the "Three cards in one» policy (industrialization, innovation and human capital) is a problem that Chinese economic reforms intensively solve. Currently, the country has 24 provinces in promotion of this work. Among them there are 19 provinces and municipalities in the process of implementation of the "Three cards in one» policy. The provinces participate in the program of simplification of procedure for receiving of work permits, organizing their tax services and improving the quality of life in general. The policy «Three cards in one» allows to reduce the time of registration of migrants, increases the efficiency of labor market and service market, reduces business costs, improves entrepreneurial enthusiasm among migrants, and increases the scale of investor migration [13].

Besides, the government of China is working to simplify the procedure for professional approval of qualification requirements, to improve the efficiency of allocation of the human resources. The State Council of Executive Sessions of the Communist Party of China in order to further improvement of effectiveness of the human resources' allocation and in accordance with the precondition of maintaining the acceptability of qualifications continues to work on the growth of professional qualifications and identification of migrants' licenses. In the provinces where there is no legal and institutional basis to master the various types of professional qualifications in various departments, it is necessary to create a mechanism for own licensing and certification. While the system of professional qualifications becomes strong and identification based on control and management improves, it is necessary to correct violations in implementation of job projects, to improve the standards of vocational and professional skills for all professions that are under the procedure of national classification. Professions without such standards will be excluded from the classifier of professions. With the gradual establishment of industry associations, societies and other social organizations, many Chinese provinces reevaluate the level of professional qualifications of migrants. The new migration policy reduces the threshold of entrance to the labor market in many areas of public entrepreneurship, allows the greater participation of the public in the process of entrepreneurial innovation, and promotion of employment [13].

On the other hand, although the situation of migrants in China has been ignored for many years, now the improvement of their living and working conditions has become the focus of attention for the Chinese leadership. Facing the increasing number of complex social, economic, environmental and other problems, the China's government gave priority to balanced and harmonious development of Chinese society, with a special emphasis on problems and needs of individual. This fact means that in coming years one of the central problems for China's government will be the problem of softening of negative social and economic consequences of large-scale internal migration [14].

\section{CONCLUSION}

Thus, at present days we can note the intensification of internal migration of population from villages to cities in China as a result of socioeconomic and innovative development of the country. On the base on the research, the following conclusions can be drawn.

Migration of population, including labor migration, is the process of settlement of territories and their economic development, also development of productive forces of society. The current trend of migration in China is the social changes of recent decades, which have radically changed the political and social situation in the country. China is experiencing a very large migration boom now. At different periods many developing countries also experienced a high scale of migration, but unlike them, China was faced with the high degree of intensity of migration flows under conditions of beginning of innovative development. 
For China - country with huge territorial differences, unevenness of socio-economic and innovative development, migration of population has always been important. The main donors of the labor force are the central, western and northern provinces. The main recipients are the eastern provinces and cities of central subordination.

Scientists identify two main factors that shape the trends of development of internal migration: demographic and economic. The study of demographic factor answers the questions «how many people», "what structure and composition migrants have». The study of economic factor shows why people move from villages to cities, which causes make them to leave their homes.

The "army» of Chinese migrants has a significant influence on economy and livelihoods of cities, which are the final destination of their migration potential. There is a permanent restructuring of number of urban residents in favor of visitors and people who live in them for less than 6 months. Proportion of those who do not have permanent registration and those whose registration does not coincide with their actual place of residence, has increased from $21.16 \%$ to $23.85 \%$.

\section{REFERENCES}

1. Zhocao Yu (2014). Demographic factors of China's socio-economic development // Economic Theory. No. 1. P. 85-91.

2. Yu Y. (2016). Social stratification after the formation of China // Sociology. No.1. P.87-92.

3. Migration of population: theory, policy: the textbook (2013). Edited by O.D. Vorobyeva, A.V. Topilin. Moscow: Publ. house Economic Education. - 364 p.

4. Zhujun Dean, Kovalev M.M., Novik V.V. (2014). The phenomenon of China's economic development: scientific publication. Minsk: Publ. house BSU Publishing Center. - 446 p.

5. Report of Jiang Zemin at the 16th All-China Congress of the CPC (second part) [Electronic resource] // Newspaper «People's Daily» on-line in English. URL: http://russian.people.com.cn//zhuanti/partycongress/bao2.html.

6. Huang Anang, Meng Hongyuan (2017). The rise of modern China. Comprehensive national power and great strategy [Electronic resource] // Almanac "East» About the Situation in Russia. No. 2 (43). URL: http://www.situation.ru/app/j_art_1195.htm.

7. Internal migration continues to be one of the main problems for China [Electronic resource] // Official website of the National Television of China. URL: http://cctv.cntv.cn/2014/05/15/VIDE1400134561794338.shtml.

8. Andreev E. (2015) Doubling of China: What will be the reversal of the rule «One family one child» [Electronic resource] // Information portal of RBC of Russia. URL: http://www.rbc.ru/opinions/society/11/11/2015/.

9. Krasova E.V., Yang X.X. (2016). Modern trends in the formation of human resources as a factor in China's sustainable economic development // Economic and Social Changes: Facts, Trends, Forecast. No. 3 (45). P. 205-220.

10. Krasova E.V., Jin Yanhong, Zhao Lihua (2016). Unevenness in the socio-economic development of the regions of China as the result of sustainable growth of Chinese economy // Vector of Science of Togliatti State University. No. 2 (25). P. 42-49.

11. Statistical Yearbook of China in 2016 [Electronic resource] // Official site of the National Bureau of Statistics of China. URL: http://www.stats.gov.cn/tjsj/ndsj/2016/indexeh.htm.

12. International Migration [Electronic Resource] // The World FactBook. URL: https://www.cia.gov/library/publications/the-world-factbook/geos/xx.html.

13. 2015 年 中国 劳动力 市场 发展 报告 [Report on the development of the labor market in China in 2015. Publ. house of Beijing Pedagogical University. Beijing, 2015]. - 383 p.

14. Bao Gun (2016). Main social and economic problems of migrant workers of modern China // Research and Development of Students Collection of Materials of the International Student Scientific and Practical Conference. Cherepovets: P. 103-106. 